\title{
THE PHASE DISTRIBUTION OF PLUTONIUM AND AMERICIUM IN PRODUCTION ELECTROREFINING
}

\author{
James C. Brown
}

\section{LEGAL NOTICE}

Ths report was prepared as an account of Government sponsored work. Neither the United States, nor the Commission, nor any person acting on behalf of the Commisston

A Makes any warranty or representation, expressed or implied, with respect to the accuracy, completeness, or usefulness of the informatson contained in this report, or that the use of any information, apparatus, method, or process disclosed in this report may not infringe privately owned rights; or

B. Assumes any liabilties with respect to the use of, or for damages resultang from the use of any information, apparatus, method, or process disclosed in this report.

$\mathrm{As}$ used in the above, "person acting on behall of the Commission" includes any employee or contractor of the commission, or employee of such contractor, to the extent that such employee or contractor of the Commission, or employee of such contractor prepares, disseminates, or provides access to, any information pursuant to his employment or contract disseminates, or provides access to, any information pursuant
with the Commission, or his employment with such contractor.

\footnotetext{
THE DOW CHEMICAL COMPANY ROCKY FLATS DIVISION

P. O. BOX 888

GOLDEN, COLORADO 80401

U. S. ATOMIC ENERGY COMMISSION CONTRACT AT(29-1)-1106
} 


\section{DISCLAIMER}

This report was prepared as an account of work sponsored by an agency of the United States Government. Neither the United States Government nor any agency Thereof, nor any of their employees, makes any warranty, express or implied, or assumes any legal liability or responsibility for the accuracy, completeness, or usefulness of any information, apparatus, product, or process disclosed, or represents that its use would not infringe privately owned rights. Reference herein to any specific commercial product, process, or service by trade name, trademark, manufacturer, or otherwise does not necessarily constitute or imply its endorsement, recommendation, or favoring by the United States Government or any agency thereof. The views and opinions of authors expressed herein do not necessarily state or reflect those of the United States Government or any agency thereof. 


\section{DISCLAIMER}

Portions of this document may be illegible in electronic image products. Images are produced from the best available original document. 
RFP-1065

\section{CON TENTS}

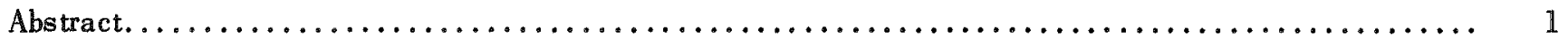

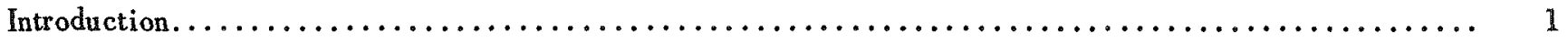

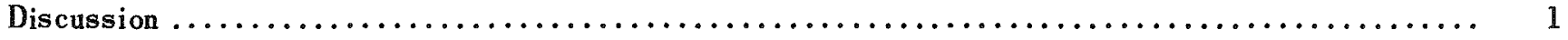

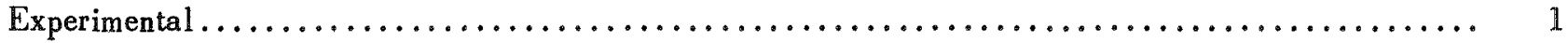

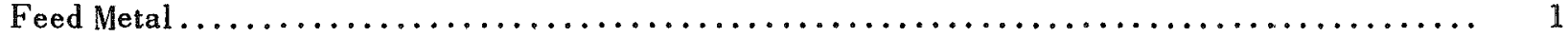

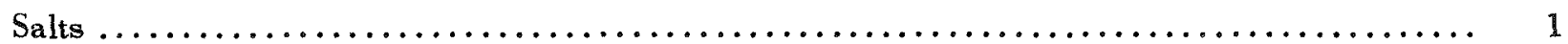

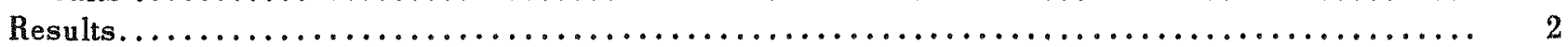

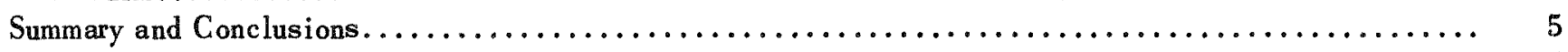

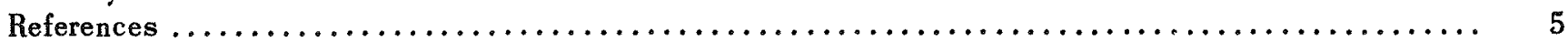




\section{The Phase Distribution of Plutonium and Americium in Production Electrorefining}

James C. Brown

Abstract: Plutonium can be purified by a nonaqueous, electrorefining technique (1). ${ }^{1}$ In such a process, most of the plutonium is recovered as pure metal at the cathode, while some remains as an impure anode and some remains in the molten-salt electrolyte. Americium 241, an impurity contained in the original feed plutonium, has high radioactivity. Thus, the removal and concentration of americium pose certain problems.

To investigate the distribution of plutonium and americium in sodium, potassium, and magnesiumchloride salts; in product metal; and in anode; some 31 electrorefining runs were made. The final results are summarized. Briefly, findings show after electrorefining that the average americium content of the feed metal was 960 parts per million (ppm) and of the salt, $1230 \mathrm{ppm}$. The average americium concentration in the product metal was $267 \mathrm{ppm}$. An average of 35.2 grams of plutonium per run was found in the salts as plutonium chloride.

In runs where feed anodes depleted to less than 200 grams, impurities other than americium were found in the salts. After electrorefining, an average of 362 grams of plutonium was retained in the salts also as metal globules.

\section{INTRODUCTION}

In earlier work with electrorefining processes at Rocky Flats, insufficient data were acquired to determine the distribution of americium and plutonium in the salts produced. Plutonium and americium enter the salt phase by reacting with magnesium chloride (2). After electrorefining, a certain amount of plutonium in the salt phase is found in the form of metal globules.

The objectives of the current work were to investigate the distribution of plutonium and americium in the salt, product metal, and anode. Salts, containing equal molar mixtures of sodium and potassium chlorides with 2.5-weight percent magnesium chloride, were precast to fit the six electrorefining cells used. Feed metal for the experiments included impure gallium-stabilized, delta-phase plutonium. Electrorefining feed anodes were cast in plutonium-foundry furnaces. A series of 31 electrorefining runs were made. Equipment details and results of the electrorefining process used have been given by Long and Schweikhardt $(2,3)$. Results on plutonium purification and process efficiency have been summarized by R. L. Standifer in an internal report.

\section{DISCUSSION}

\section{Experimental:}

A series of 31 electrorefining runs were made in six production cells to demonstrate the feasibility of a purification technique as a production process. Data were collected to determine the distribution of the americium and plutonium in the various phases. Experimental conditions are described.

FEED METAL - Plutonium feed material was 1-weight percent gallium-stabilized, delta-phase metal containing about 2000 parts per million (ppm) total impurities. The average weight of the plutonium feed anodes was 3227 grams and the average americium content was $960 \mathrm{ppm}$. The result shows an equivalent of 3.10 grams of americium per run in the feed for the 31 runs.

SALTS - Salt charges were precast and contained 730 grams of potassium chloride, 570 grams of sodium chloride, and 34 grams of magnesium chloride. The salts were mixed in a ball mill for 30 minutes and the salt mixture poured into a quartz crucible. The crucible was placed in a resistance furnace and heated to $800^{\circ} \mathrm{C}$ until the salts became molten. The molten salts were purged with anhydrous hydrochloric acid $(\mathrm{HCl})$ for 15 minutes to remove any moisture and then poured into a quartz mold to cool. Salt cakes were removed from the mold and placed in a drying oven for storage until used.

At the start of a run, no americium or plutonium was contained in the salt. Average weight of the salt before electrorefining was 1320 grams. After electrorefining, average weight of the salts was 1310 grams.

\footnotetext{
${ }^{1}$ See references.
} 
Salts and plutonium metal in the molten state were stirred for about 48 hours during the electrorefining runs. Details of the electrorefining process and experimental conditions for the 31 runs have been fully described in earlier reports $(2,3)$. Plutonium and americium contents in the salts were determined by radiochemical analysis, and impurities in the salt by emission spectrographic analysis.

Plutonium was recovered from the salts, ceramics, and anode heels by aqueous processes. Salts and ceramics were crushed and the plutonium removed by leaching in $7 \mathrm{~N}$ nitric acid $\left(\mathrm{HNO}_{3}\right)$. The leached ceramics were then washed with water and discarded. The solution, containing some undissolved plutonium oxide, was filtered and the undissolved plutonium oxide washed with water to remove excess chlorides.

The oxide was recovered by routine production methods. The solution containing plutonium chloride was passed through anion-exchange columns (using Dowex-1(B) $)^{2}$ for recovery. Anode heels were dissolved in a solution containing $3 \mathrm{~N} \mathrm{HNO}_{3}$ and $0.2 \mathrm{~N}$ hydrofluoric acid (HF). The plutonium was recovered by routine production methods.

\section{Results:}

Americium is thermodynamically more active than plutonium. Therefore, at equilibrium, it is apparent that americium concentrates in the salts. The chemical reaction (Equation 1) for americium (Am) during electrorefining is:

$$
\left.2 \mathrm{Am}^{0} \text { (in } \mathrm{Pu}\right)+3 \mathrm{MgCl}_{2} \rightleftarrows 2 \mathrm{AmCl}_{3}+3 \mathrm{Mg}^{0}
$$

The reaction takes place until the americium approaches equilibrium with the salts, anode feed, and product metal.

Table I shows the americium distribution in the feed metal, product metal, and electrorefining salts for all 31 runs. The average americium content of the plutonium-product metal after electrorefining was $267 \mathrm{ppm}$ or 0.66 grams in 2493 grams (average) of product. This is equal to 21 percent of the americium in the original feed.

During the 31 runs, an average of 74 percent of the americium in the feed material was retained in the

\footnotetext{
${ }^{2}$ Trademark of The Dow Chemical Company, Midland, Michigan.
}

salts as americium chloride. This is equal to 1.61 grams of americium in 1320 grams of salt. The total americium content of the salt and product metal, by analysis, averaged 2.27 grams. The average americium content of the plutonium feed material was 3.10 grams. The difference in americium concentration between the feed metal and the salts and product metal was 0.83 grams, and is assumed to be in the anode heels. The anode heels were not sampled for americium.

The chemical reaction (Equation 2) of plutonium with magnesium chloride present in the molten electrorefining salt is:

$$
2 \mathrm{Pu}^{0}+3 \mathrm{MgCl}_{2} \rightleftarrows 2 \mathrm{PuCl}_{3}+3 \mathrm{Mg}^{0}
$$

The reaction is necessary to produce plutonium ions in the salt solution, prior to electrorefining. It takes place during the 30 -minute stirring time prior to electrolysis. At the start of the run, there were 34.0 grams of magnesium chloride in 1320.0 grams of salt. From this, the maximum amount of plutonium as chloride that could be present in the salt is calculated as follows:

$$
\begin{aligned}
\frac{\left(34.0 \text { grams } \mathrm{MgCl}_{2}\right) \times 2(239 \text { molecular weight } \mathrm{Pu})}{3\left(94.3 \text { molecular weight } \mathrm{MgCl}_{2}\right)} \\
=57.0 \text { grams plutonium }\left(\mathrm{Pu}^{2}\right) \\
\text { as plutonium chloride }\left(\mathrm{PuCl}_{3}\right)
\end{aligned}
$$

Analysis of the salts indicated an average of only 32.5 grams of plutonium as chloride in the salts after the run. A small amount of magnesium chloride $\left(\mathrm{MgCl}_{2}\right.$, approximately $1 \mathrm{gram}$ ) is consumed by reaction with americium. The evidence thus indicates that all of the magnesium chloride is not consumed during the runs. This is not unexpected, as an equilibrium constant of near unity can be estimated for Equation 2 from free energy of formation data (4). A similar result was observed during earlier work at Rocky Flats (5). Four of the runs have not been included in the average because product metal globules were in the salt samples.

The reactions for electrorefining of plutonium are as follows:

$$
\begin{array}{ll}
\text { Anode Reaction: } & \mathrm{Pu}^{0} \rightarrow \mathrm{Pu}^{+3}+3 \mathrm{e}^{-} \\
\text {Cathode Reaction: } & \mathrm{Pu}^{+3}+3 \mathrm{e}^{-} \rightarrow \mathrm{Pu}^{0}
\end{array}
$$

The more noble impurities concentrate in the anode and the less noble concentrate in the salt. The amount of less noble impurities in the salts was 
TABLE 1. Americium in the Feed Metal, Product Metal, and Electrorefining Salt.

\begin{tabular}{|c|c|c|c|c|c|c|}
\hline $\begin{array}{l}\text { Run } \\
\text { No. }\end{array}$ & $\begin{array}{c}\text { Feed } \\
\text { Metal } \\
\text { Weight } \\
\text { (grams) } \\
\end{array}$ & $\begin{array}{c}\text { Product } \\
\text { Metal } \\
\text { Weight } \\
\text { (grams) } \\
\end{array}$ & $\begin{array}{c}\text { Americium in } \\
\text { Feed Metal } \\
\text { (parts per million) }\end{array}$ & $\begin{array}{c}\text { Americium in } \\
\text { Product Metal } \\
\text { (parts per million) }\end{array}$ & $\begin{array}{l}\text { Percent } \\
\text { Americium } \\
\text { Extracted } \\
\end{array}$ & $\begin{array}{l}\text { Americium in } \\
\text { Salt by Analysis } \\
\text { (grams per gram) }\end{array}$ \\
\hline $1-F$ & 3340 & 2865 & 980 & 200 & 80 & $1.58 \times 10^{-3}$ \\
\hline $4-B$ & 3400 & 2336 & 980 & 188 & 81 & $1.80 \times 10^{.33}$ \\
\hline $3-D$ & 3381 & 2858 & 980 & 224 & 75 & $1.70 \times 10^{-3}$ \\
\hline $2-E$ & 3300 & 2636 & 980 & 222 & 78 & $1.40 \times 10^{-3}$ \\
\hline $8-C$ & 3228 & 2754 & 806 & 180 & 78 & $1.30 \times 10^{-3}$ \\
\hline$* 7-B$ & 3274 & 1909 & 926 & $* 898$ & $* 4$ & $* 2.50 \times 10^{-5}$ \\
\hline 6-A & 3350 & 2414 & 926 & 252 & 73 & $1.90 \times 10^{-3}$ \\
\hline 9-D & 3272 & 2778 & 806 & 187 & 77 & $1.10 \times 10^{-3}$ \\
\hline $10-\mathrm{F}$ & 3275 & 2844 & 806 & 255 & 69 & $1.30 \times 10^{-3}$ \\
\hline $16-F$ & 3345 & 3157 & 806 & 299 & 63 & $5.40 \times 10^{-4}$ \\
\hline $15-E$ & 3252 & 2697 & 975 & 343 & 65 & $1.30 \times 10^{-3}$ \\
\hline $13-\bar{C}$ & 3214 & 2871 & 1069 & 263 & 75 & $3.34 \times 10^{-44}$ \\
\hline 14-D & 3220 & 2153 & 1226 & 632 & 49 & $1.30 \times 10^{\mathrm{m}^{3}}$ \\
\hline $11-\mathrm{A}$ & 3224 & 3062 & 1069 & 249 & 77 & $1.60 \times 10^{-3}$ \\
\hline$* 12-B$ & 3226 & 1363 & 1069 & $* 626$ & $* 42$ & $4.5 \times 10^{-4}$ \\
\hline $17-\mathrm{A}$ & 3104 & 2483 & 936 & 218 & 77 & None \\
\hline $23-\mathrm{F}$ & 3218 & 2545 & 936 & 167 & 82 & $1.60 \times 10^{-3}$ \\
\hline $26-\mathrm{D}$ & 3248 & 2779 & 936 & 390 & 59 & $1.50 \times 10^{-3}$ \\
\hline $25-C$ & 3211 & 2585 & 936 & 181 & 81 & $1.40 \times 10^{-3}$ \\
\hline $18-B$ & 3029 & 2052 & 913 & 148 & 84 & $1.10 \times 10^{-3}$ \\
\hline $21-E$ & 3193 & 2715 & 1226 & 429 & 75 & None \\
\hline $27-A$ & 3245 & 2324 & 913 & 263 & 71 & $1.78 \times 10^{-3}$ \\
\hline $28-B$ & 3096 & 1785 & 913 & 210 & 77 & $4.06 \times 10^{-4}$ \\
\hline $29-\mathrm{C}$ & 3187 & 2622 & 1028 & 310 & 70 & $1.26 \times 10^{-3}$ \\
\hline $30-\mathrm{D}$ & 3201 & 2529 & 1028 & 216 & 79 & $7.1 \times 10^{-4}$ \\
\hline $31-E$ & 3150 & 2610 & 913 & 431 & 52 & $8.9 \times 10^{-4}$ \\
\hline $32-\mathrm{F}$ & 3177 & 2529 & 913 & 237 & 74 & $1.20 \times 10^{-3}$ \\
\hline $5-\mathrm{A}$ & 3210 & 2089 & 925 & 42 & 95 & $* * 1.85 \times 10^{-2}$ \\
\hline $22-\mathrm{F}$ & 3054 & 2659 & None & 465 & & None \\
\hline $20-\mathrm{D}$ & 3205 & 1944 & 935 & None & & None \\
\hline 19-A & 3203 & 2353 & 935 & None & & None \\
\hline \multirow[t]{3}{*}{ Average: } & 3227 & 2493 & 960 & 267 & 74 & $1.23 \times 10^{-3}$ \\
\hline & & $* \mathrm{Th}$ & uns in the $B$ cell wer & ormal and were not & & \\
\hline & & $\begin{aligned} * * \mathrm{~V} \\
\text { th }\end{aligned}$ & $\begin{array}{l}\text { not included in the } \\
\text { hers, and may be } d\end{array}$ & $\begin{array}{l}\text { It is a factor of } \\
\text { alytical error. }\end{array}$ & & \\
\hline
\end{tabular}

low, except when the feed anode was depleted to less than 200 grams.

Tables II and III show the distribution of impurities in the salt phase. Analysis of the salts for runs where the anode was less than 200 grams is shown in Table II. Analysis of salts for electrorefining runs in which the anodes weighed more than 200 grams is shown in Table III.

In some of the runs plutonium-product metal appeared as small globules at the salt-metal interface. Table IV shows the amount of plutonium metal retained as globules after electrorefining as determined by analysis and material balance (weight difference).
In general as calculated by weight differences, the plutonium lost from the metal phase minus the plutonium found in the salt by analysis is equal to the amount of plutonium metal globules in the salt. The metal globules would be undetected in the samples taken for salt analysis. The quantity of globules varied from run to run and cell to cell (see Table IV). The amount of globules in the salt was thought to be related to the amount of metallic sodium produced during the run which in turn was caused by abnormally high voltages. Figure 1 shows possible causes for the production of metallic sodium and consequently plutonium globules.

Cell B showed a much greater plutonium loss to the salts by weight difference than any of the other 
TABLE II. Impurities in Electrorefining Salts after Runs Where Anodes Weighed Less Than 200 Grams.

\begin{tabular}{|c|c|c|c|c|c|c|c|}
\hline \multirow{2}{*}{$\begin{array}{l}\text { Run } \\
\text { No. }\end{array}$} & \multirow{2}{*}{$\begin{array}{l}\text { Anode } \\
\text { Weight } \\
\text { (grams) }\end{array}$} & \multicolumn{6}{|c|}{$\begin{array}{l}\text { Impurity Concentration } \\
\text { (parts per million) } \\
\end{array}$} \\
\hline & & Aluminum & Chromium & Copper & Iron & Gallium & Nickel \\
\hline $3-D$ & 157.0 & 400 & 200 & 50 & 500 & $\begin{array}{c}<2.5 \\
\text { (percent) }\end{array}$ & 400 \\
\hline 9-D & 98.0 & 200 & 20 & 100 & 10 & 3000 & $<10$ \\
\hline $10-F$ & 63.0 & 500 & 200 & 50 & 50 & $\begin{array}{c}<2.5 \\
\text { (percent) }\end{array}$ & 50 \\
\hline $29-\mathrm{C}$ & 129.0 & 100 & 200 & $<10$ & 100 & $<100$ & 40 \\
\hline
\end{tabular}

TABLE III. Impurities in Electrorefining Salts after Runs Where Anodes Weighed More Than 200 Grams.

\begin{tabular}{|c|c|c|c|c|c|c|c|}
\hline \multirow{2}{*}{$\begin{array}{l}\text { Rum } \\
\text { No. }\end{array}$} & \multirow{2}{*}{$\begin{array}{r}\text { Anode } \\
\text { Weight } \\
\text { (grams) }\end{array}$} & \multicolumn{6}{|c|}{$\begin{array}{l}\text { Impurity Concentration } \\
\text { (parts per million) }\end{array}$} \\
\hline & & Aluminum & Chromium & Copper & Iron & Gallium & Nickel \\
\hline $5-A$ & 701 & $<10$ & $<10$ & $<10$ & $<10$ & $<10$ & $<10$ \\
\hline $6-A$ & 448 & $<10$ & $<10$ & $<10$ & $<10$ & $<10$ & $<10$ \\
\hline $27-A$ & 467 & $<10$ & $<10$ & 40 & 40 & $<10$ & $<10$ \\
\hline $30-D$ & 648 & $<10$ & $<10$ & $<10$ & $<10$ & $<10$ & $<10$ \\
\hline
\end{tabular}

TABLE IV. The Amount of Plutonium Retained in the Salts as Calculated by

Weight Difference and as Determined by Analysis. (All amounts are in grams.)

\begin{tabular}{|c|c|}
\hline Cel & \\
\hline Weight & \\
\hline Difference & Analysis \\
\hline
\end{tabular}

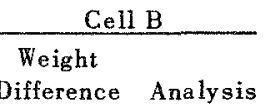

$\frac{\text { Gell C }}{\text { Weight }}$ Difference Analysis

$\frac{\text { Gell D }}{\begin{array}{c}\text { Weight } \\ \text { Difference Analysis }\end{array}}$

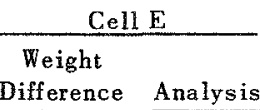

\begin{tabular}{|c|c|}
\hline 483 & 24 \\
\hline 488 & 57 \\
\hline 44 & 33 \\
\hline 444 & None \\
\hline 322 & None \\
\hline 454 & 36 \\
\hline
\end{tabular}

371

\begin{tabular}{l}
581 \\
654 \\
837 \\
741 \\
683 \\
\hline
\end{tabular}

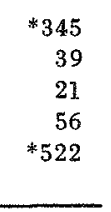

699

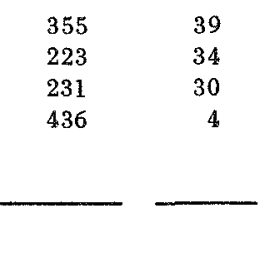

311

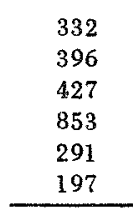

416

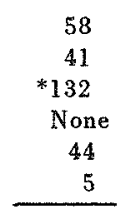

37

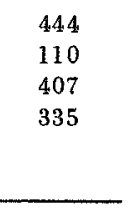

324

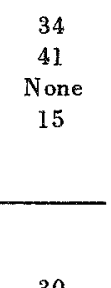

30

$\frac{\text { Cell F }}{\text { Weight }}$\begin{tabular}{c} 
Difference Analysis \\
\hline
\end{tabular}
Difference

Analysis

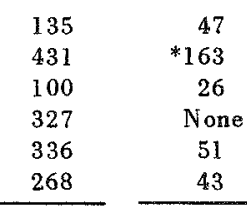

266

42

* Metal Globules:

334

660

284

379

294

* These analyses were not averaged because plutonium metal was found in the salt samples.

* The weight difference minus the analysis data equals the gram weight of the metal globules.

FIGURE 1, Possible Causes of Metallic Sodium Production.

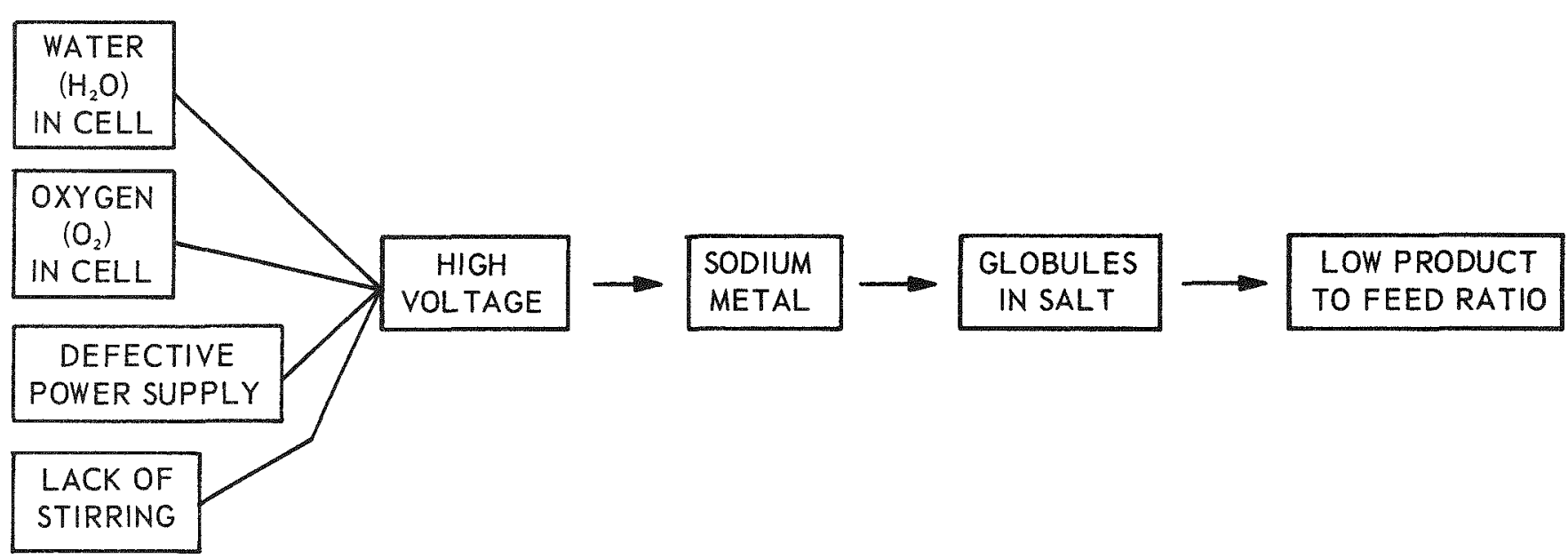


cells. At the end of the runs, when Cell $B$ was opened, evidence was always given of metallic sodium. The direct-current electrolysis power supply was a possible cause of the metallic sodium generated in Cell B. Run conditions and equipment were the same for all cells, with the exception of the electrolysispower supplies which differed for each cell.

Plutonium loss to the salt in Cell $\mathrm{F}$ was less than in the other cells, averaging only 266 grams by weight difference. A commercial Regatron ${ }^{3}$ direct-current power supply was used on the two runs in Cell $F$ in which the least amount of plutonium was lost to the

${ }^{3}$ Electron Measurements Company, Eatontown, New Jersey.

FIGURE 2. One of the Electrorefining Cells Used in the Experiments.

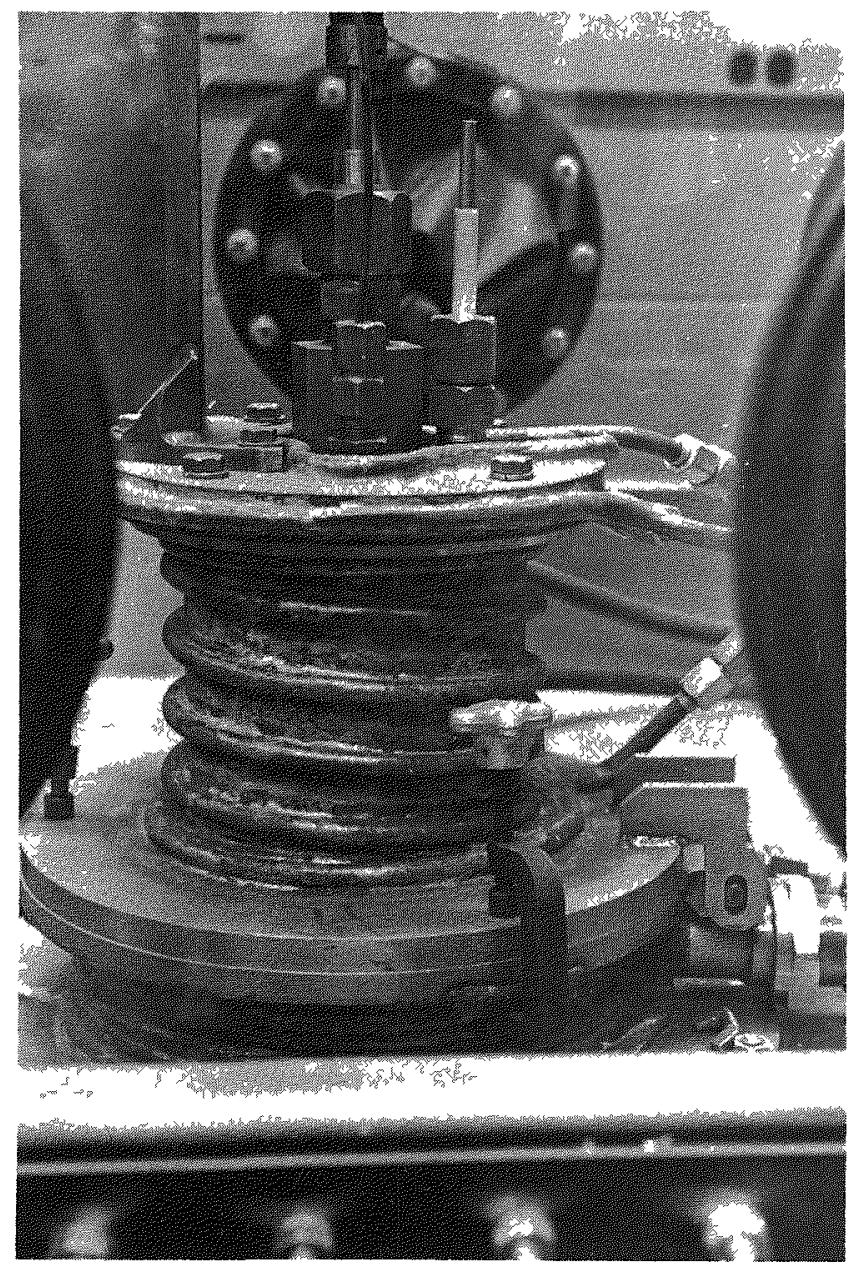

salts. The results indicate that the power supplies are a significant factor in making efficient electrorefining runs.

In Figure 2, one of the cells used in the experiments is shown.

\section{SUMMARY AND CONCLUSIONS}

Phase distribution of americium and plutonium was determined in a series of 31 electrorefining runs. It was found that an average of 74 percent $(1230 \mathrm{ppm})$ of the americium was retained in the salts as americium chloride. An average of 21 percent $(267 \mathrm{ppm})$ of the americium was found in the plutonium product. An average of one percent or 32.5 grams of plutonium was retained in the salts as plutonium chloride. An average of 11.2 percent or 362.0 grams of plutonium was retained in the salts as finely divided, plutoniumproduct metal.

Impurities other than americium appeared in the salts from electrorefining runs in which the feed anodes were depleted to less than 200 grams.

\section{REFERENCES}

1. L. J. Mullens, Jr. Plutonium Electrorefining Cell. U. S. Patent No. 3,098,028 filed by the U. S. Atomic Energy Commission, Washington, D. C. February 16, 1961.

2. J. L. Long and R. D. Schweikhardt. Electrorefining of Plutonium. U. S. Patent No. 3,282,806 filed by the U. S. Atomic Energy Commission, Washington, D. C. November 1, 1966.

3. Jack L. Long and Robert D. Schweikhardt. Plutonium Electrorefining at Rocky Flats. RFP-871.

Rocky Flats Division, The Dow Chemical Company, Golden, Colorado. April 17, 1967.

4. A. Glassner. The Thermochemical Properties of the Oxides, Fluorides and Chlorides to $2500^{\circ} \mathrm{K}$. ANL-5750. Argonne National Laboratory, Argonne, Illinois. 1962.

5. J. L. Long. Private Communication. 1964. 